\title{
Astyanax totae, a new characid species (Teleostei: Characidae) from the upper rio Iguaçu basin, southeastern Brazil
}

\author{
Carolina Ferreira Haluch and Vinícius Abilhoa
}

\begin{abstract}
A new species of characid fish, Astyanax totae, is described from a small tributary in the upper drainage of the rio Iguaçu, Paraná basin, Brazil. The new species is distinct from most species of Astyanax by the vertically elongated humeral spot, slightly expanded above the lateral line to posterodorsal margin of opercle, followed by a midlateral dark stripe expanded from the humeral region to the median caudal-fin rays, maxilla with 2 to 5 teeth (usually 3 ) and 15 to 18 branched anal-fin rays.

É descrita uma nova espécie de caracídeo coletada em um pequeno tributário do trecho superior do rio Iguaçu, bacia do rio Paraná, Brasil. Astyanax totae distingue-se das demais espécies do gênero pela presença de mancha umeral verticalmente alongada, sendo a parte superior mais alargada em contato com a margem postero-dorsal do opérculo, seguida de uma faixa lateral escura que se prolonga desde a região umeral até os raios medianos da nadadeira caudal, maxilar com 2 a 5 dentes (freqüentemente 3 ) e 15 a 18 raios bifurcados na nadadeira anal.
\end{abstract}

Key words: Characiformes, Neotropical, Taxonomy, Astyanax scabripinnis.

\section{Introduction}

The genus Astyanax Baird \& Girard, 1854 is diverse and widespread in freshwaters of South America, including about one hundred nominal species (Lima et al., 2003). The systematic of the genus is still unresolved and the taxonomic status of some species is not completely clear.

In the last few years, the diagnoses of Astyanax-like forms that inhabit fast-water streams have shown body shape characters similar to the subspecies of Astyanax scabripinnis diagnosed by Eigenmann $(1921,1927)$ and to the $A$. scabripinnis species complex of Moreira-Filho \& Bertollo (1991), with an elongated body (2.6 to 3.6 body depth in SL), low anal-fin ray counts (less than 25), head heavy and body deepest and heaviest over middle of pectoral fins. These body shape characters are apparently common to other Astyanax-like forms that inhabit fast-water streams, and some morphometric and karyotypic studies have found that these isolated populations are in fact undescribed species (Moreira Filho \& Bertollo, 1991; Bertaco \& Malabarba, 2001; Melo, 2001), leading us to believe that Eigenmann's definition of $A$. scabripinnis should be investigated, as stated by Bertaco \& Malabarba (2001).

During a field expedition to the upper portions of the rio Iguaçu basin, a new characid species was collected that fits the morphological features of the A. scabripinnis species complex. As a contribution to the knowledge of this poorly known ichthyofauna, we herein describe this species.

\section{Material and Methods}

The examined specimens are deposited in the Museu de História Natural Capão da Imbuia, Prefeitura Municipal de Curitiba (MHNCI), Museu de Ciências e Tecnologia, Pontifícia Universidade Católica do Rio Grande do Sul (MCP), Museu de Zoologia da Universidade de São Paulo (MZUSP), Núcleo de Pesquisas em Limnologia, Ictiologia e Aqüicultura, Universidade Estadual de Maringá (NUP), and Museu Nacional, Rio de Janeiro (MNRJ). Other institutional abbreviations follow Bertaco \& Malabarba (2001).

Measurements and counts were taken following Fink \& Weitzman (1974). All measurements were taken as straight-line distance using calipers, and were expressed as percentage of $\mathrm{SL}$, except for those taken in the head, which are recorded as percentage of the head length. For counts recorded in the description, the frequency of each count is provided in parenthesis, and an asterisk indicates those of the holotype. Specimens were cleared and stained for vertebral, supraneurals, gill-rakers, teeth and procurrent caudal-fin-ray counts according to

Grupo de Pesquisas em Ictiofauna (GPIc), Museu de História Natural Capão da Imbuia (MHNCI), Prefeitura de Curitiba. Rua Prof. Benedito Conceição 407, 82.810-080 Curitiba, PR, Brazil. e-mail:(VA) vabilhoa@uol.com.br 


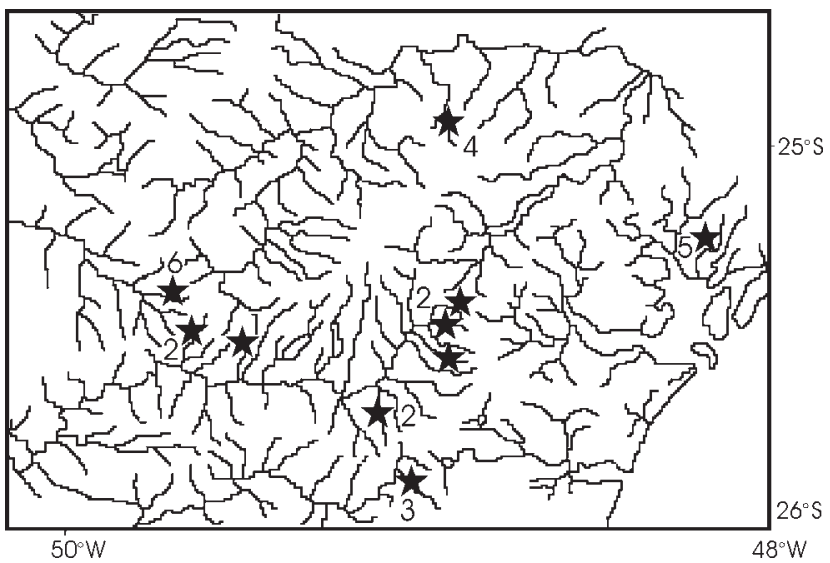

Fig. 1. Geographic distribution of the material examined (stars): (1) Astyanax totae sp. n., rio Tortuoso basin, upper rio Iguaçu basin; (2) Astyanax sp. D, upper rio Iguaçu drainages; (3) Astyanax sp. F, rio da Várzea, rio Iguaçu basin; (4) Astyanax janeiroensis, rio Ribeira basin; (5) Astyanax aff. scabripinnis, rio Morato, coastal drainage of southeastern Brazil; (6) Astyanax sp., rio Tibagi, upper rio Paraná system.

the method of Taylor \& Van Dyke (1985). Vertebrae count includes those corresponding to the Weberian apparatus and the terminal centrum was counted as one vertebrae.

The nomenclature of the comparative material from the rio Iguaçu basin follows Severi \& Cordeiro (1994) and Ingenito et al. (2004): Astyanax sp. B, Astyanax sp. C, Astyanax sp. D, Astyanax sp. E and Astyanax sp. F. Morphometric and meristic data of the types of A. scabripinnis, A. laticeps, A. jenynsii, and Deuterodon longirostris follow Bertaco \& Malabarba (2001). Morphometric data of $A$. intermedius and $A$. janeiroensis follow Melo (2001). Comparative material from the $A$. scabripinnis species complex from other drainages was analyzed (Fig. 1).

Statistical tests of differences among measurements and counts were computed using Statistica 6.0,2001, StatSoft Incorporation. Parametric comparison tests (one-way analysis of variance) were performed, after normality and equal variance were tested.

\section{Results}

\section{Astyanax totae, new species}

(Figs. 2-5; Table 1)

Holotype. MHNCI 10305, 61.1 mm SL, Brazil, Paraná, Balsa Nova, distrito do Bugre, rio Cascata, tributary of rio Tortuoso, an affluent of rio Iguaçu, $25^{\circ} 29^{\prime} \mathrm{S}, 49^{\circ} 39^{\prime} \mathrm{W}$, D. P. Azevedo Filho \& E. L. Rosa, 26 May 2002.

Paratypes. (Same locality and collectors as holotype): MHNCI 10306, 21, 34.4-73.4 mm SL (2 c\&s), 26 May 2002. MHNCI 10338, 54, 32.3-71.3 mm SL, 9 Jan 2002. MCP 37562, 8, 49.1-81.9 mm SL, 11 Jul 2002. MCP 37561, 15, 39.2-64.3 mm SL, 9 Jan 2002. MCP 37560, 4, 47.1-69.2 mm SL, 10 Jan 2002. NUP 4099, 16, 41.9-56.3 mm SL, 23 Jun 2002. MNRJ 28652, 11, 36.9-66.3 mm SL, 9 Jan 2002.
Diagnosis. Astyanax totae differs from other species of the genus by the lower number of branched anal-fin rays (iii-v, $15-18$, mean $=16.7, \mathrm{n}=30$, versus $20-45$ in most species of the genus). Other species of Astyanax with the same number of branched anal-fin rays are $A$. jenynsii $(13-15, \mathrm{n}=3)$, A. laticeps $(18-21, \mathrm{n}=5)$, A. intermedius $(14-21, \mathrm{n}=89)$, A. brachypterygium $(13-15, \mathrm{n}=43)$, A. cremnobates $(15-17, \mathrm{n}=59)$, A. leonidas $(17$ $21, \mathrm{n}=16)$, and $A$. paranae (17-23). Astyanax totae differs from the syntypes of $A$. jenynsii (NMW 57534,3) and types of $A$. laticeps (ANSP 21852, 1; ANSP 21743, 4) by the shorter upper jaw length compared to head length (21.8-28.7\%, mean $=26.6, \mathrm{SD}=1.3$ versus $35.9-39.5 \%$, mean $=37.4$ in $A$. jenynsii and $43.4-45.7 \%$, mean $=44.6$ in $A$. laticeps ). The upper jaw length is also longer in $A$. intermedius (37.5-53.1\%, mean $=44.4$, $\mathrm{SD}=2.7)$. Astyanax totae is distinguished from $A$. brachypterygium and $A$. cremnobates by the larger orbital diameter relative to head length $(25.4-42.6 \%$, mean $=35.7$, $\mathrm{SD}=4.1$ versus $24.8-34.8 \%$, mean $=29.0$ in $A$. brachypterygium, and 28.1-35.4\%, mean=32.1 in A. cremnobates; Fig. 4). Although the orbital diameter in $A$. totae partially overlaps the range of $A$. brachypterygium and A. cremnobates, significant differences using one-way analysis of variance test were found among the species ( $\mathrm{F}=46.83, \mathrm{P} \leq 0.001$; Fig. 5). Astyanax totae is further distinguished from $A$. brachypterygium and A. cremnobates by the presence of a single humeral spot vertically elongated (versus two black humeral spots, second one diffuse). The presence of 2 to 5 (usually 3 ) maxillary teeth distinguishes $A$. totae from $A$. leonidas that has only one maxillary tooth long and slender. It was not possible to analyze the type material of $A$. paranae, but some characteristics present in the original description (Eigenmann, 1914:47) discriminate the new species from $A$. paranae: the larger orbital diameter $(25.4-42.6 \%$, mean $=35.7, \mathrm{SD}=4.1$ in $A$. totae versus "eye 5 in the head in the old" in $A$. paranae) and the larger snout length compared to head length (14.6-24.1\%, mean=19.9, $\mathrm{SD}=2.2$ in $A$. totae versus "snout 3.5 " in $A$. paranae).

Description. Morphometrics of holotype and 29 paratypes are presented in Table 1. Body moderately elongated, compressed. Greatest body depth at dorsal fin origin, 2.8 to 3.4 times in SL.

Dorsal profile of head straight. Predorsal profile of body slightly convex from the supraoccipital spine through dorsalfin origin, and almost straight from the end of dorsal-fin base to caudal peduncle. Dorsal-fin base straight, posteroventrally inclined. Ventral profile of head and body convex from lower lip to anal fin origin. Body profile along anal fin base straight. Caudal peduncle elongated with dorsal and ventral profiles nearly straight.

Snout prominent and rounded, shorter than orbital diameter. Posteroventral edge of third infraorbital distant from preopercle, leaving wide naked border between these bones. Mouth terminal, angled posteroventrally. Maxilla reaching a vertical line through the middle of the orbit, with 2-5 tricuspid teeth (mostly $3^{*}, \mathrm{n}=20$ ), decreasing in size anteroposteriorly. 


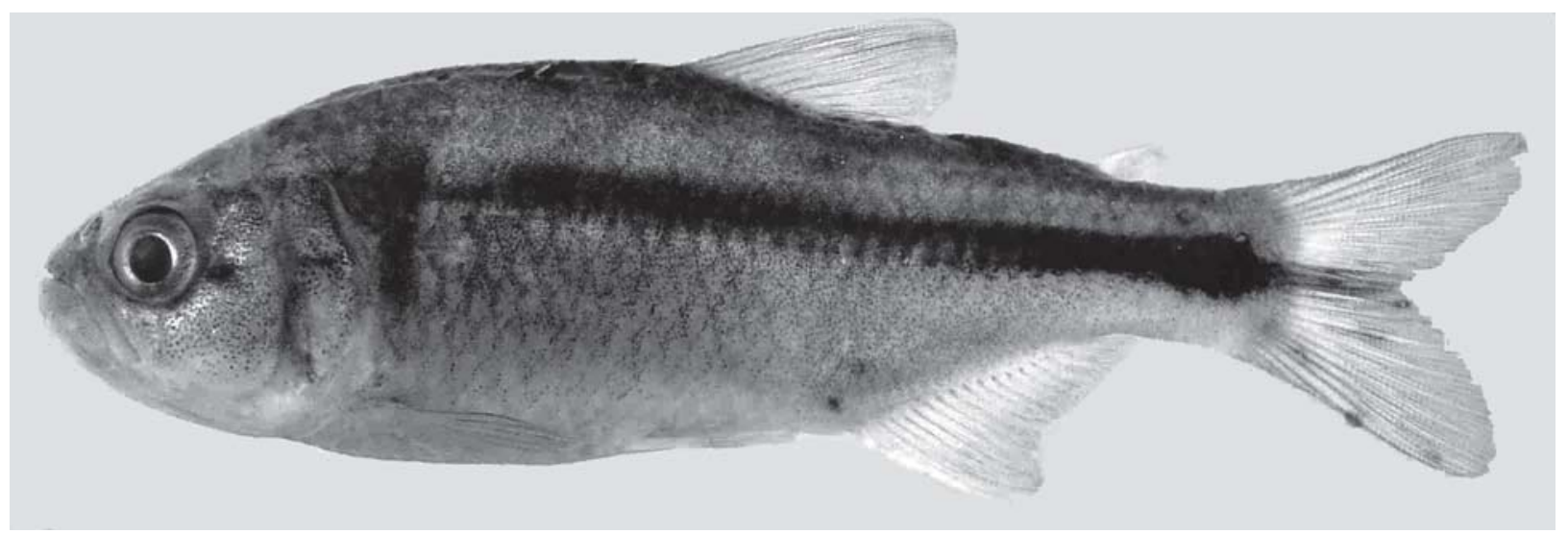

Fig. 2. Astyanax totae, holotype, MHNCI 10305, $61.1 \mathrm{~mm} \mathrm{SL}$, rio Cascata, tributary of rio Tortuoso, an affluent of the rio Iguaçu.

Premaxillary teeth in two rows. Outer row with 2 (1), 3 (9), 4* (19) or 5(1) tricuspid teeth, with central cuspid developed. Inner row with 5 teeth gently expanded distally, slightly compressed at distal tips. Symphysial tooth narrower and deeper, with 4 or 5 cusps. Second, third and fourth teeth with 5 to 7 cusps. Fifth tooth smaller, with 3 or 4 cusps. In all teeth central cusp slightly larger than remaining ones. Dentary with 7 teeth. First four anterior teeth larger, usually with 5 cusps, followed by 3 very smaller tricuspid teeth.

Dorsal-fin rays ii, 9. Posterior margin of dorsal fin slightly rounded. Dorsal-fin origin distance from snout tip nearly equal or larger than caudal-fin base. Pelvic-fin origin situated anterior to vertical through dorsal-fin origin, with 8 rays. Tip of pelvic fin reaching anal-fin origin only in small specimens. Pectoral-fin rays 10 (2), 11 (3), 12 (8), 13* (15), 14 (2). Pectoralfin distal tips not reaching pelvic-fin, except in small specimens. Anal fin with iii-iv, 15 (4), 16* (7), 17 (14), 18 (5) rays. Caudal fin forked, lobes similar in size, slightly rounded.

Lateral line complete, with 34 (1), 35 (4), 36 (13), 37 (7), 38* (5) perforated scales. Six series of scales between dorsal-fin origin and lateral line, not including scale of predorsal series situated just anterior to first dorsal-fin ray. Four series of scales between lateral line and pelvic-fin insertion. Circumpeduncular scales 15(3), 16(2), 17 (10), 18*(11), 19 (3).

In two cleared and stained specimens procurrent caudalfin rays 7 dorsal and 10 ventral. First gill arch with 19 gill rakers ( 7 epibranchial, 9 ceratobranchial, 1 on cartilage between epibranchial and ceratobranchial, and 2 hypobranchial), vertebrae 35 or 36 ( 16 or 17 precaudal and 19 caudal).

Color in alcohol. Preserved specimens with dorsal and lateral parts of the body medium brown to pale yellowish. Dark chromatophores concentrated on middorsal surface of head and body. Humeral spot vertically elongated, slightly expanded above the lateral line to posterodorsal margin of opercle, followed by a midlateral dark stripe extended from the humeral region to the median caudal-fin rays. Lateral stripe placed on two series of scales, wider on caudal peduncle. Humeral spot narrow, three scales wide above lateral line. All fins hyaline, with scattered dark chromatophores pigmentation.
Sexual dimorphism. The presence of small hooks on the pelvic fin and anal fin of males is the only external sexually dimorphic feature found in this species.

Etymology. The specific epithet totae comes from Tota, nickname of Adelinyr Azevedo de Moura Cordeiro, in recognition of her contribution to MHNCI fish collection.

Distribution. Known only from the type locality, rio Cascata, tributary of rio Tortuoso, an affluent of the rio Iguaçu basin in Paraná State, Brazil.

Ecological notes. Astyanax totae was collected in a headwater stream with clear water, light to moderate current water and bottom with stones, sand and moderate amount of vegetal debris. The most frequent food items found in fifteen stomachs were microcrustaceans (Cladocera and Copepoda),

Table 1. Morphometric data of Astyanax totae, based on the holotype (MHNCI 10305) and paratypes (MHNCI 10306, $\mathrm{n}=$ 21; $\mathrm{MCP} 37562, \mathrm{n}=8)$. $\mathrm{SD}=$ standard deviation.

\begin{tabular}{lcccc}
\hline Characters & Holotype & Range & Mean & SD \\
\hline Standard length (mm) & 61.4 & $34.4-81.8$ & 54.1 & 11.6 \\
& Percents of standard length & & \\
Predorsal distance & 56.9 & $50.4-57.1$ & 55.1 & 1.4 \\
Prepelvic distance & 51.0 & $46.9-52.0$ & 49.4 & 1.2 \\
Prepectoral distance & 29.2 & $27.8-32.4$ & 29.5 & 1.1 \\
Preanal distance & 69.1 & $64.2-71.4$ & 67.6 & 1.8 \\
Body depth & 33.4 & $30.0-35.0$ & 32.5 & 1.4 \\
Caudal peduncle depth & 13.0 & $11.9-14.0$ & 13.1 & 0.5 \\
Caudal peduncle length & 13.0 & $9.5-15.1$ & 12.9 & 1.3 \\
Dorsal fin length & 24.2 & $21.5-27.2$ & 24.9 & 1.3 \\
Pelvic fin length & 14.6 & $13.3-19.0$ & 16.4 & 1.8 \\
Pectoral fin length & 18.9 & $17.3-25.0$ & 20.8 & 2.1 \\
Anal fin length & 18.1 & $16.3-23.8$ & 19.8 & 2.0 \\
Head length & 31.2 & $27.9-32.8$ & 29.7 & 1.1 \\
& & & & \\
Snout length & 16.9 & $14.6-24.1$ & 19.9 & 2.2 \\
Upper jaw length & 26.1 & $21.8-28.7$ & 26.6 & 1.3 \\
Orbital diameter & 32.6 & $25.4-42.6$ & 35.7 & 4.1 \\
Interorbital length & 31.8 & $26.9-40.8$ & 36.6 & 2.9 \\
\hline
\end{tabular}




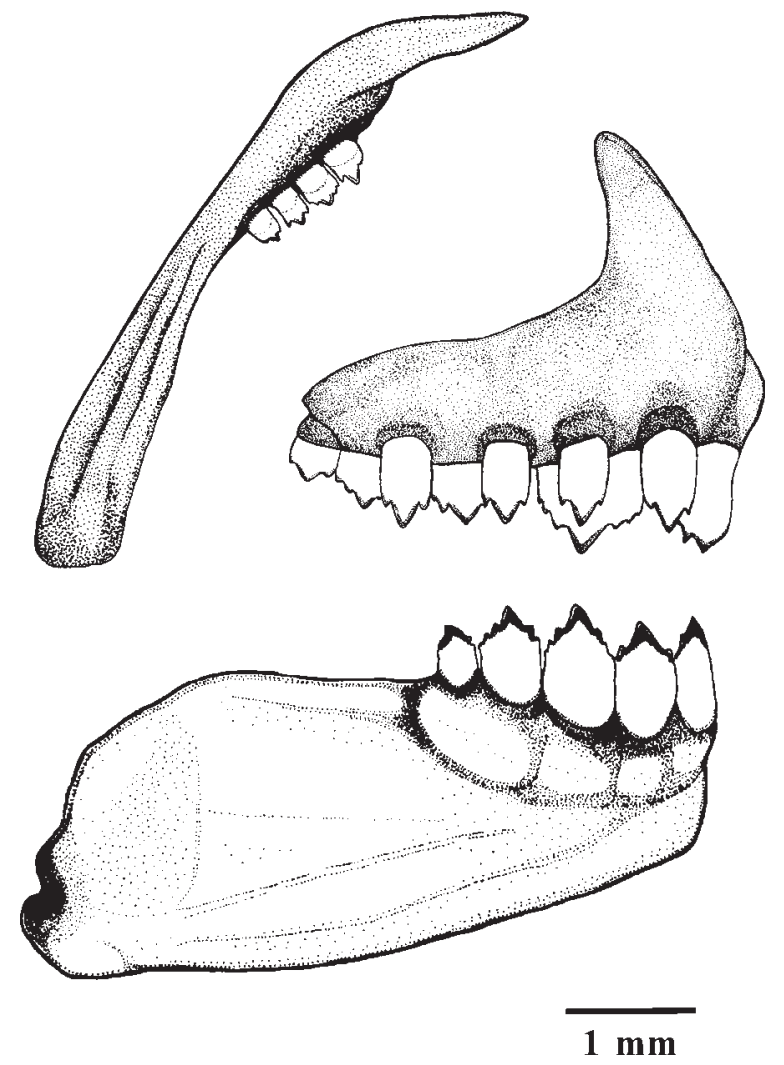

Fig. 3. Astyanax totae, MHNCI 11248, $56.3 \mathrm{~mm}$ SL. Maxilla (top-left), premaxilla (top-right) and lower jaw (bottom); lateral view; right side; scale $1.0 \mathrm{~mm}$.

insect larvae (Chironomidae), adult insects and plants fragments (probably allochthonous material). Underwater observations through snorkeling in pool environments identified small groups of individuals collecting food items carried by the current (drift) or feeding on items coming from the forest adjacent to the river. The fact that the stream flows within a remaining fragment of Araucaria Forest in the First Paraná Plateaux is important for the foraging behavior of the species herein described, since some important food items are directly and indirectly dependent on the forest covering.

\section{Discussion}

Four Astyanax species were previously described from the rio Iguaçu basin: A. gymnogenys Eigenmann, 1911, A. scabripinnis paranae Eigenmann, 1927, A. leonidas Azpelicueta et al., 2002, and A. ita Almirón et al., 2002. The number of analfin rays separates $A$. totae (15 to 18 ) from $A$. gymnogenys (21 to 22) and $A$. ita (23 to 28), and the presence of only one maxillary tooth distinguish $A$. leonidas from the new species (2 to 5, usually 3 ). Furthermore, mature males of $A$. leonidas possess bony hooks in rays in all fins, except in the dorsal fin, whereas A. totae shows small hooks on the pelvic and anal-fin.

The new species here described also differs from Eigenmann's Astyanax scabripinnis subspecies, all recognized as valid species by Bertaco \& Malabarba (2001) and

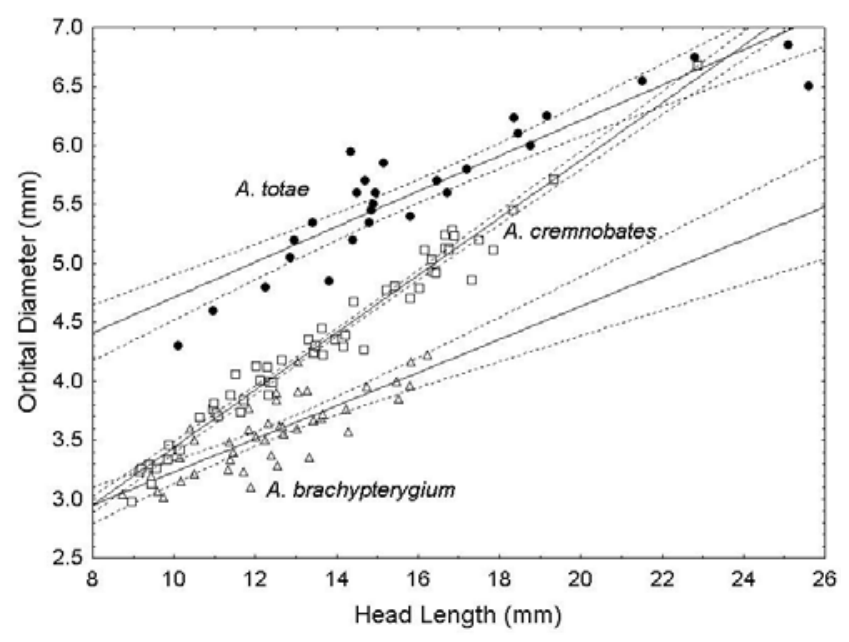

Fig. 4. Orbital diameter as function of Head Length in Astyanax totae, A. cremnobates and A. brachypterygium. Note that the confidence intervals (95\%) do not overlap in $A$. totae and $A$. brachypterygium, indicating significant difference. In head lengths of about 8 to $21 \mathrm{~mm}$ the $95 \%$ confidence intervals do not overlap in $A$. totae and A. cremnobates, indicating a significant difference in these size ranges.

Lima et al. (2003). Astyanax totae differs from the holotype of A. scabripinnis (BMNH 1917.7.14:15) and from A. rivularis by the lower number of branched anal-fin rays (15-18 versus 21 in A. scabripinnis and 20-25 in A. rivularis). Characters distinguishing $A$. jenynsii, A. laticeps, $A$. intermedius, and $A$. paranae from $A$. totae are discussed under diagnosis.

Astyanax longirostris was transferred to the monophyletic genus Deuterodon by Lucena \& Lucena (2002) based on the shape of the maxillary bone and tooth arrangement. Astyanax totae also differs from the syntypes of $D$. longirostris (NMW 57633,2) by the longer head length relative to standard length $(27.9-32.8 \%$, mean $=29.7, \mathrm{SD}=1.1$ versus $26.2-26.7 \%$ ) and by the shorter snout length compared to head length (14.6-24.1\%, mean=19.9, $\mathrm{SD}=2.2$ versus $29.3 \%)$.

Among other species occurring in the rio Iguaçu basin recorded by Severi \& Cordeiro (1994), A. totae can be discriminated by the lower body depth $(30.0-35.0 \%$, mean $=32.5$, $\mathrm{SD}=1.4$ of SL) from Astyanax sp. B (35.2-42.5\%, mean $=38.5$, $\mathrm{SD}=1.6$ of SL) and Astyanax sp. C (35.8-44.9\%, mean $=39.7$, $\mathrm{SD}=2.2$ of SL). The head length in A. totae (27.9-32.8\%, mean $=29.7, \mathrm{SD}=1.1$ of $\mathrm{SL}$ ) is also relatively longer than Astyanax sp. B (22.6-26.7\%, mean $=24.2, \mathrm{SD}=0.8$ of SL), Astyanax sp. C (22.0-25.4\%, mean $=23.4, \mathrm{SD}=0.7$ of SL), and Astyanax $\mathrm{sp}$. E (24.0-27.8\%, mean=26.1, SD=0.9 of SL). The presence of a humeral spot vertically elongated, slightly expanded above the lateral line until the opercle margin, and midlateral dark stripe expanded from the humeral spot to the median caudal-fin rays further differs $A$. totae from Astyanax sp. E (humeral spot and midlateral stripe faint) and Astyanax sp. D (humeral spot well-defined, black and round, with a vertically elongated line extended anteroventrally). Furthermore, Astyanax sp. D shows small hooks on the pectoral fins 


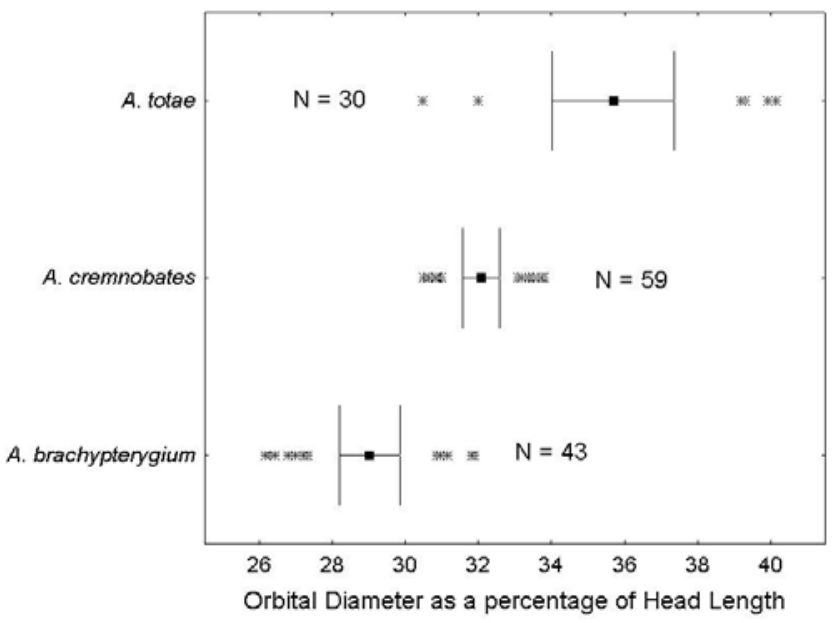

Fig. 5. Anova box-whisker plots of the Orbital diameter as a percentage of Head Length in Astyanax totae, A. cremnobates and $A$. brachypterygium. Significant differences using oneway analysis of variance test were found among the species $(\mathrm{F}=46.83, \mathrm{P} \leq 0.001)$. Mean represented by squares, and confidence intervals $(95 \%)$ as lateral bars of box-whisker plots. Asterisks represent extreme values.

of males, unlike the new species. Astyanax totae is distinguished from Astyanax sp. F by the shorter snout length compared to head length $(14.6-24.1 \%$, mean $=19.9, \mathrm{SD}=2.2$ versus $24.6-32.6 \%$, mean=28.2, $\mathrm{SD}=2.1$ ).

Astyanax totae differs from $A$. janeiroensis and Astyanax aff. scabripinnis (from coastal drainage of southeastern Brazil - MHNCI 7824, MHNCI 7844, MHNCI 7858) also by the lower number of branched anal-fin rays (15-18 versus 19-24 in A. janeiroensis and 19-23 in Astyanax aff. scabripinnis) and by the humeral spot vertically elongated, slightly expanded above the lateral line until the opercle margin. In these species, like Astyanax sp. D, the humeral spot is well-defined, black and round, with vertically elongated line extended anteroventrally. Furthermore, the number of gill rakers in the ceratobranchial is lower in A. totae (9) in comparison with Astyanax aff. scabripinnis (10) from coastal drainage of Paraná. In addition, $A$. totae has 2 gill rakers in the hypobranchial, whereas Astyanax aff. scabripinnis has one. The two cleared and stained specimens of $A$. totae also have lower number of procurrent caudal fin rays.

Recent collecting efforts in the upper rio Iguaçu basin yielded seven species of Astyanax (Ingenito et al., 2004). Only two species fit the morphological features of the $A$. scabripinnis species complex: A. totae and Astyanax sp. D. Astyanax totae clearly differs from the second species, and is the first species of the genus described for the rio Iguaçu headwaters. The fact that the specimens are so far known only in one stream indicate that conservation programs should be established.

Comparative material: Astyanax janeiroensis: Brazil: Paraná State: rio Ribeira de Iguape basin: MHNCI 5921, 28 (2 c\&s), ribeirão
Pocinha, 8 Nov 1988; MZUSP 60163, 6, córrego do Franco, 2447’'S 48³3'W, 22 Mar 2000; MZUSP 71873, 2, rio Caçador, 24³5'S $49^{\circ} 19^{\prime} \mathrm{W}, 6$ Jan 2000; MZUSP 79510, 5, stream tributary of rio Três Barras, $25^{\circ} 18^{\prime}$ S 4934'W, 16 May 2002. Astyanax aff. scabripinnis: Brazil: Paraná State: coastal drainage: MHNCI 7824, 4, small affluent of rio Morato, 11 Jun 1994; MHNCI 7844, 4, same data of MHNCI 7824, 12 Jun 1994; MHNCI 7858, 20 (2 c\&s), small affluent of rio Morato, 25 Jun 1994. Astyanax sp.: Brazil: Paraná State: rio Tibagi basin: MHNCI 8138, 11 ( 2 c\&s), rio Lageado do Pito, 28 Mar 1990. Astyanax sp.: Brazil: São Paulo State: rio Paranapanema basin: MHNCI 9144, 14 (2 c\&s), road SP261, stream tributary of rio Claro, $22^{\circ} 47^{\prime} \mathrm{S} 49^{\circ} 10^{\prime} \mathrm{W}, 9 \mathrm{Jul} 2000$; MNRJ 27970, 31, small tributary of rio das Almas, $24^{\circ} 08^{\prime} \mathrm{S}$ 48²0’W, 7 Nov 2002. Astyanax sp.: Brazil: Paraná State: rio Iguaçu basin: MNRJ 27964, 15, UHE Foz do Areia, 4 Jul 1992. Astyanax sp. F: MHNCI 9146, 15, stream tributary of rio da Várzea, Mar 1999; MHNCI 9147, 14, same data of MHNCI 9146. Astyanax sp. D: MHNCI 8926, 3, small creck that flows to rio Palmital, $25^{\circ} 24^{\prime} \mathrm{S}$ 4909'W, 27 May 1999; MHNCI 9142, 7, rio Miringuava, 25³7’'S $4^{\circ} 05^{\prime}$ W, 9 Jan 2002; MHNCI 9153, 6, Eng. Bley Railroad Station, 253' S 49 44'W, 5 Oct 2001; MHNCI 9174, 1, rio Piraquara, 2529'S 49॰05'W, 1 Apr 2000; MHNCI 9341, 2, rio Passaúna, 13 Aug 1991, MHNCI 9383, 5 (3 c\&s), rio Piraquara, 18 Aug 2000; MHNCI 10374, 6, rio Iraí, Jan 1999; MCP 37559, 20, rio Cascata, rio Tortuoso basin, Jun 2003.

\section{Acknowledgments}

We are much indebted to Damil P. de Azevedo Filho for the fieldwork, that resulted in the discovery of the present species, and for ecological data. Luiz Duboc helped us during the clearing and staining process. We are grateful to Leonardo Ingenito (MNRJ), Vinícius Bertaco (MCP), Luiz Malabarba (MCP), and Paulo Lucinda (UFT) for useful comments on the manuscript. We are also grateful to Luiz Malabarba for morphometric information of Astyanax brachypterygium and $A$. cremnobates. CFA received financial support from IMAP/PMC - Instituto Municipal de Administração Pública / Prefeitura de Curitiba. Material was collected with authorization IBAMA-DIREN n.004/2000. Two anonymous referees improved the paper.

\section{Literature Cited}

Almirón, A. E., M. M. Azpelicueta \& J. R. Casciotta. 2002. Astyanax ita sp. n. - a new species from the Río Iguazú basin, in Argentina (Teleostei, Characiformes, Characidae). Zoologische Abhandlungen, 52:3-10.

Azpelicueta, M. M., J. R. Casciotta \& A. E. Almirón. 2002. Two new species of the genus Astyanax (Characiformes, Characidae) from the Paraná river basin in Argentina. Revue Suisse de Zoologie, 109(2): 243-259.

Baird, F. S. \& C. Girard. 1854. Descriptions of new species of fishes collected in Texas, New Mexico and Sonora, by Mr. John H. Clark, on the U.S. and Mexican Boundary Survey, and in Texas by Capt. Stewart van Vliet, U.S.A. Proceedings of the Academy of Natural Science of Philadelphia, 1854: 24-29. 
Bertaco, V. A. \& L. R. Malabarba. 2001. Description of two new species of Astyanax (Teleostei: Characidae) from headwater streams of Southern Brazil, with comments on the "A. scabripinnis species complex". Ichthyological Exploration of Freshwaters, 12(3): 221-234.

Eigenmann, C. H. 1911. New characins in the collection of the Carnagie Museum. Annals of the Carnagie Museum, 8(1): 164-180.

Eigenmann, C. H. 1914. Some results from studies of South American fishes. IV. New genera and species of South American fishes. Indiana University Studies, 20: 44-48.

Eigenmann, C. H. 1921. The American Characidae. Memoirs of the Museum of Comparative Zoology, 43(3): 209-310.

Eigenmann, C. H. 1927. The American Characidae. Memoirs of the Museum of Comparative Zoology, 43(4): 311-428.

Fink, W. L. \& S. H. Weitzman. 1974. The so-called cheirodontin fishes of Central America with descripitions of two new species (Pisces: Characidae). Smithsonian Contributions to Zoology, 172: 1-46.

Ingenito, L. F. S., L. F. Duboc \& V. Abilhoa. 2004. Contribuição ao conhecimento da ictiofauna do Alto Iguaçu, Paraná, Brasil. Arquivos de Ciências Veterinárias e Zoologia da Unipar 7(1): 23-36.

Lima, F. C. T., L. R. Malabarba, P. A. Buckup, J. F. P. Silva, R. P. Vari, A. Harold, R. Benine, O. T. Oyakawa, C. S. Pavanelli, N. A. Menezes, C. A. S. Lucena, M. C. S. L. Malabarba, Z. M. S. Lucena, R. E. Reis, F. Langeani, L. Cassati, V. A. Bertaco, C. Moreira \& P. H. F. Lucinda. 2003. Genera Incertae Sedis in Characidae. Pp: 106-169. In: Reis, R. E., S. O. Kullander \& C. Ferraris (Eds.). Check List of Freshwater Fishes of South and Central America. Edipucrs, Porto Alegre, $729 \mathrm{p}$.
Melo, F.A.G. 2001. Revisão taxonômica das espécies do gênero Astyanax Baird \& Girard, 1854, (Teleostei: Characiformes: Characidae) da região da Serra dos Órgãos. Arquivos do Museu Nacional, 59: 1-46.

Moreira Filho, O. \& L. A. Bertollo. 1991. Astyanax scabripinnis (Pisces: Characidae), a species complex. Revista Brasileira de Genética, 14(2): 331-357.

Severi, W. \& A. A. M. Cordeiro. 1994. Catálogo de peixes da bacia do rio Iguaçu. IAP/GTZ, Curitiba, 128p.

Taylor, W. R. \& G. C. V. Dyke. 1985. Revised procedures for staining and clearing small fishes and other vertebrates for bone and cartilage. Cybium, 9: 107-119.

Weitzman, S. H. \& L. R. Malabarba. 1998. Perspectives about the phylogeny and classification of the Characidae (Teleostei: Characiformes). Pp: 161-170. In: Malabarba, L. R., R. E. Reis, R. P. Vari, Z. M. S. Lucena \& C. A. S. Lucena. Phylogeny and Classification of Neotropical Fishes. Edipucrs, Porto Alegre, 603p.

Received May 2005 Accepted September 2005 